University of Nebraska - Lincoln

DigitalCommons@University of Nebraska - Lincoln

1975

\title{
A Disease of Freshwater Fishes Caused by Tetrahymena corlissi Thompson, 1955, and a Key for Identification of Holotrich Ciliates of Freshwater Fishes
}

\author{
Glenn L. Hoffman \\ US Fish and Wildlife Service \\ M. Lando \\ National Zoological Park, Washington, D.C. \\ J. E. Camper \\ National Fish Hatchery \\ D. W. Coats \\ University of Marylan \\ J. L. Stookey \\ U. S. Army Medical Research Institute of Infectious Diseases \\ See next page for additional authors
}

Follow this and additional works at: https://digitalcommons.unl.edu/usfwspubs

Part of the Aquaculture and Fisheries Commons

Hoffman, Glenn L.; Lando, M.; Camper, J. E.; Coats, D. W.; Stookey, J. L.; and Burek, J. D., "A Disease of Freshwater Fishes Caused by Tetrahymena corlissi Thompson, 1955, and a Key for Identification of Holotrich Ciliates of Freshwater Fishes" (1975). US Fish \& Wildlife Publications. 112.

https://digitalcommons.unl.edu/usfwspubs/112

This Article is brought to you for free and open access by the US Fish \& Wildlife Service at DigitalCommons@University of Nebraska - Lincoln. It has been accepted for inclusion in US Fish \& Wildlife Publications by an authorized administrator of DigitalCommons@University of Nebraska - Lincoln. 
Authors

Glenn L. Hoffman, M. Lando, J. E. Camper, D. W. Coats, J. L. Stookey, and J. D. Burek 


\title{
A DISEASE OF FRESHWATER FISHES CAUSED BY TETRAHYMENA CORLISSI THOMPSON, 1955, AND A KEY FOR IDENTIFICATION OF HOLOTRICH CILIATES OF FRESHWATER FISHES
}

\author{
G. L. Hoffman,* M. Landolt, $\dagger$ J. E. Camper, $\neq$ D. W. Coats, $\S$ J. L. Stookey, $\|$ and J. D. Burek $\|$
}

ABSTRACT: Tetrahymena corlissi, a free-living protozoan, apparently caused the death of large numbers of guppies (Poecilia reticulatus) and occasionally other fishes, in aquaria and hatcheries at several locations. Apparently the disease occurs when the fish and protozoan populations are both at a high level of density. The signs include white spots and epidermal damage. Histologically, T. corlissi could be seen in skin, muscle, and viscera; in some there was marked inflammation, in others there was little tissue reaction. A key is presented for the identification of invasive fish ciliates: Chilodonella, Hemiophrys, Ichthyophthirius, Ophryoglena, and Tetrahymena.

Eight times during the past 3 years we have diagnosed a disease caused by a facultative parasitic ciliate of the genus Tetrahymena. Most cases involved aquarium fishes-guppies (Poecilia reticulatus) 6 times, and an unidentified aquarium fish once. One case of Tetrahymena sp. disease in catfish (Ictalurus punctatus) was found by F. Meyer in Arkansas (pers. comm.) and verified by one of us (G. L. Hoffman). It is probable that any species of freshwater fish can be affected. The diseased fish came from Arkansas, Maryland, Michigan, North Carolina, Tennessee, West Virginia, and California. This protozoan is common in nature and probably has no geographical limits in North America. A similar Tetrahymena has been reported from Europe (Ergens and Lom, 1970).

Some reports indicate that invasions of fishes by free-living ciliates of various genera may be frequent. A new fish disease was reported by Hoffman (1967) when experimental fishes (largemouth black bass, bluegill, fallfish, creek chub, sculpin) were killed by the protozoan,

Received for publication 3 July 1974.

* Eastern Fish Disease Laboratory, U. S. Bureau of Sport Fisheries and Wildlife, Kearneysville, WV 25430. Present address: U. S. Fish Farming Experimental Station, Stuttgart, AR 72160.

$\dagger$ Department of Pathology, National Zoological Park, Washington, D.C. 20009.

$\ddagger$ National Fish Hatchery, P.O. Box 158, Pisgah Forest, NC 28768.

$\S$ Zoology Department, University of Maryland, College Park, MD 20742.

\| U. S. Army Medical Research Institute of Infectious Diseases, Fort Detrick, Frederick, MD 21701.

If Pathology Department, Johns Hopkins School of Medicine, Baltimore, MD 21205.
Ophryoglena sp., while being kept in small aerated aquaria for other purposes. In extreme cases the epithelium becomes so necrotic, due to the invading protozoa, that it sloughs in patches and the fish die. Migala and Kazubski (1971, 1972) reported epizootics caused by free-living ciliates (Chilodonella cucullus, C. uncinata, Dexiostoma campylum, Glaucoma scintillans, Colpidium colpoda, Frontonia acuminata, $F$. leucas) on carp following overwintering in Polish ponds. Similarly, Purdom and Howard (1971) described epizootics in fish reared in marine fish hatcheries, caused by facultative parasitic ciliates of the species Helicostoma buddenbrooki. However, in contrast to all aforementioned ciliates, Tetrahymena has been found repeatedly and its pathogenic action has been clearly established by repeated observations and histological proof. Experimental infection, however, has not been achieved.

Beginning with Epstein's report in 1926, Tetrahymena has been reported from fishes, amphibians, baby chicks, and possibly from man. Further detail was given in reviews by Corliss (1960, 1970).

The ciliate studied by us was $T$. corlissi. It is the purpose of this paper to: (1) describe it because the description by Thompson (1955) was in abstract only, (2) present a scheme for differential diagnosis of holotrichs of fishes, and (3) describe the histopathologic changes in host tissues after they are invaded by the organism.

\section{Tetrahymena corlissi Thompson, 1955 (Figs. 1-4)}

The ciliate isolated from guppies in California which was studied by Jiri Lom (pers. 

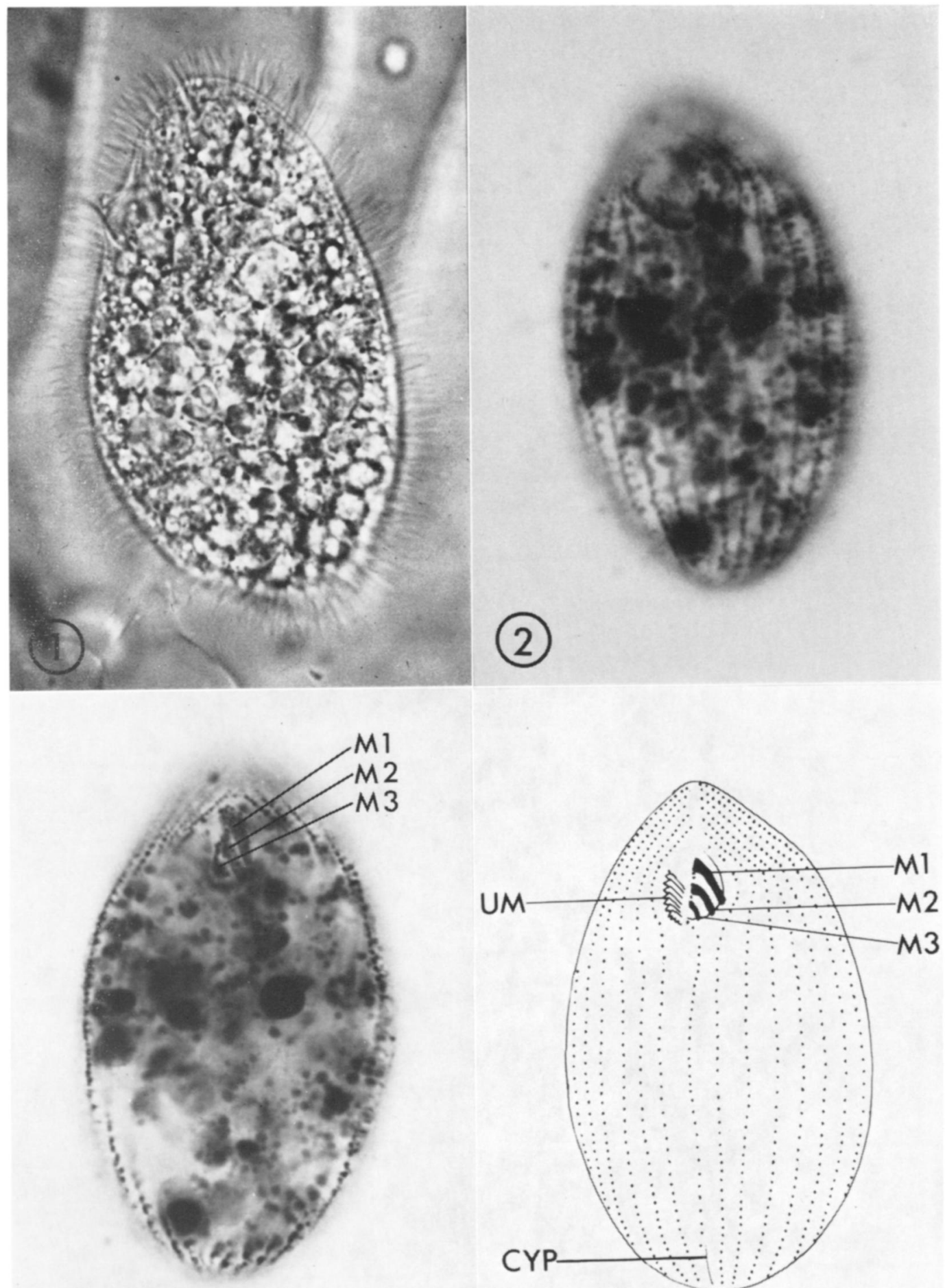

(3)

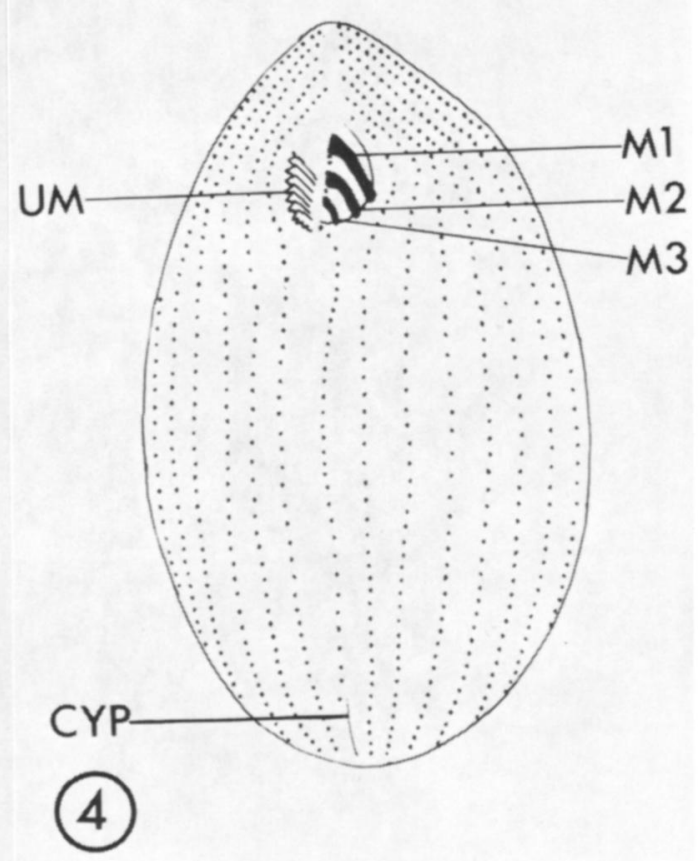


comm.) is typical T. corlissi. In material from other areas, minor variation was noted in specimens treated with the silver stain of Chatton-Lwoff (Corliss, 1953b). Most probably, however, they are variants of $T$. corlissi.

\section{Description}

Body ovate; anterior end pointed, posterior rounded, 53 ( 30 to 70 ) $\mu \mathrm{m}$ long by 20 to $45 \mu \mathrm{m}$ wide. Uniformly covered by cilia arranged in 27 (23 to 29) meridional rows; 1 or 2 rows reaching only to posterior border of buccal apparatus, the rest reach anterior pole or suture above buccal apparatus (Figs. 2, 4). This arrangement differs from that described by Thompson (1955) who stated that $T$. corlissi has 2 postoral rows. Buccal apparatus with an undulating membrane of coalescent cilia (to the observer's left) and with 3 obliquely set membranelles, each 3 ciliary rows wide (to the right). Buccal apparatus near anterior pole of body (Figs. 3, 4). An 11- by $9-\mu \mathrm{m}$ oval to round macronucleus lies near a 2- to $3-\mu \mathrm{m}$ micronucleus.

\section{Differential diagnosis}

Although the ciliate can be seen under a dissecting microscope, generic diagnosis can be made only by observing the ciliate in wet mounts or histological sections. To determine the species, impregnation methods (such as Chatton-Lwoff, Klein's, or Bodian's protargol), which reveal the "silver line system" of ciliary rows, are necessary.

The finding of small ciliates in the tissues of North American fishes indicates infection by at least one of the following: Tetrahymena corlissi, Ophryoglena, Hemiophrys, juvenile Ichthyophthirius, or possibly Chilodonella. Because of recent confusion in the identification of some of theseparticularly Tetrahymena, Ophryoglena, and Hemiophrys-we present here the comparative features (Table I) and a dichotomous key.

\section{Key to holotrich ciliates of freshwater fishes}

(does not include species described as rare facultative parasites by Migala and Kazubski, 1971, 1972, and Purdom and Howard, 1971)

1a. Macronucleus double, i.e., separate macronuclei with a micronucleus between, in either motile phase ( 54 to $70 \mu \mathrm{m}$ by 29 to $59 \mu \mathrm{m}$ ) or sessile phase; encysted on the surface; ciliary rows spirally twisted Hemiophrys

1b. Macronucleus single 2a. Body flat, dorsoventrally compressed

\section{Chilodonella}

2b. Body round in transverse section …............... 3

3a. Population consisting of individuals of conspicuously different sizes (from $40 \mu \mathrm{m}$ to about $1,000 \mu \mathrm{m}$ ), larger specimens have a horseshoe-shaped macronucleus Ichthyophthirius

3b. Population consisting of individuals of about equal size 4

4a. About 150 to $200 \mu \mathrm{m}$ by $85 \mu \mathrm{m}$; ellipsoid; macronucleus elongated; buccal apparatus with a depression in form of the number " 6 ", a refractile "watch-glass" structure in cytoplasm close to the side of the buccal apparatus. About 85 meridional ciliary rows, of which 9 are postoral. No caudal cilium

Ophryoglena

4b. About 30 by $50 \mu \mathrm{m}$; ovate to pear-shaped, with anterior end more or less pointed; macronucleus round to oval; buccal apparatus small, drop-shaped, close to anterior end. From 25 to 31 meridional ciliary rows, of which 1 or 2 are postoral. A single caudal cilium

Tetrahymena corlissi

\section{Pathology associated with $\boldsymbol{T}$. corlissi}

Grossly the infection is often seen as small $(1 \mathrm{~mm})$ white spots in the skin and musculature of the fish, accompanied by extensive sloughing of the epidermis, elevation of the scales, and a loss of equilibrium. The white spots are areas of necrosis which contain the ciliate. In the cases studied female fish died within 1 week after infection, and males in 1 to 3 weeks. The protozoans were readily seen on living fishes with a dissecting microscope and could be demonstrated easily in wet mounts (Fig. 1). Many parasites were seen in the blood vessels of the gills of one dead guppy.

Histologically, the protozoan could be seen superficially in the skin and in the musculature of the body wall (Fig. 5) and in some cases even in the coelom (Fig. 6). In most specimens the epidermis was eroded, and in others the dermis also. The extensive skeletal muscle necrosis was not accompanied by either hemorrhage or edema. Speidel (1954) demonstrated tissue destruction during invasion by

Figures 1-4. Tetrahymena corlissi Thompson, 1955, from infected guppies, $\times 1,560$. 1. Living ciliate. 2. Showing ventral somatic infraciliary pattern. Chatton-Lwoff silver stain (Corliss, 1953). 3. Ventral view showing oral membranelles, M1, M2, M3. Chatton-Lwoff silver stain. 4. Schematic representation of ventral surface showing oral membranelles (M1, M2, M3), undulating membrane (UM), and cytoproct (CYP); based on Chatton-Lwoff stained specimens (modification of Corliss, 1953b). 


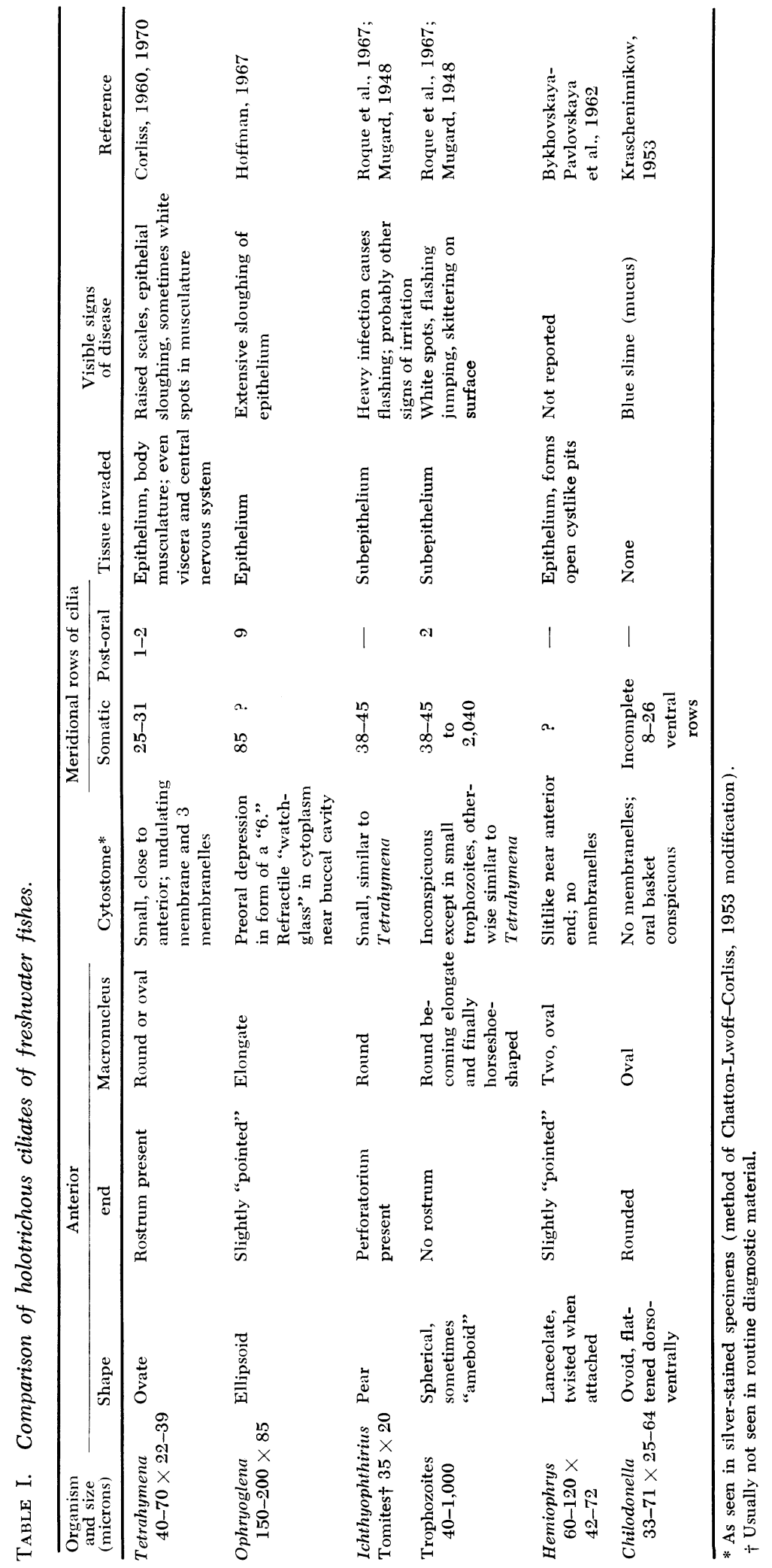




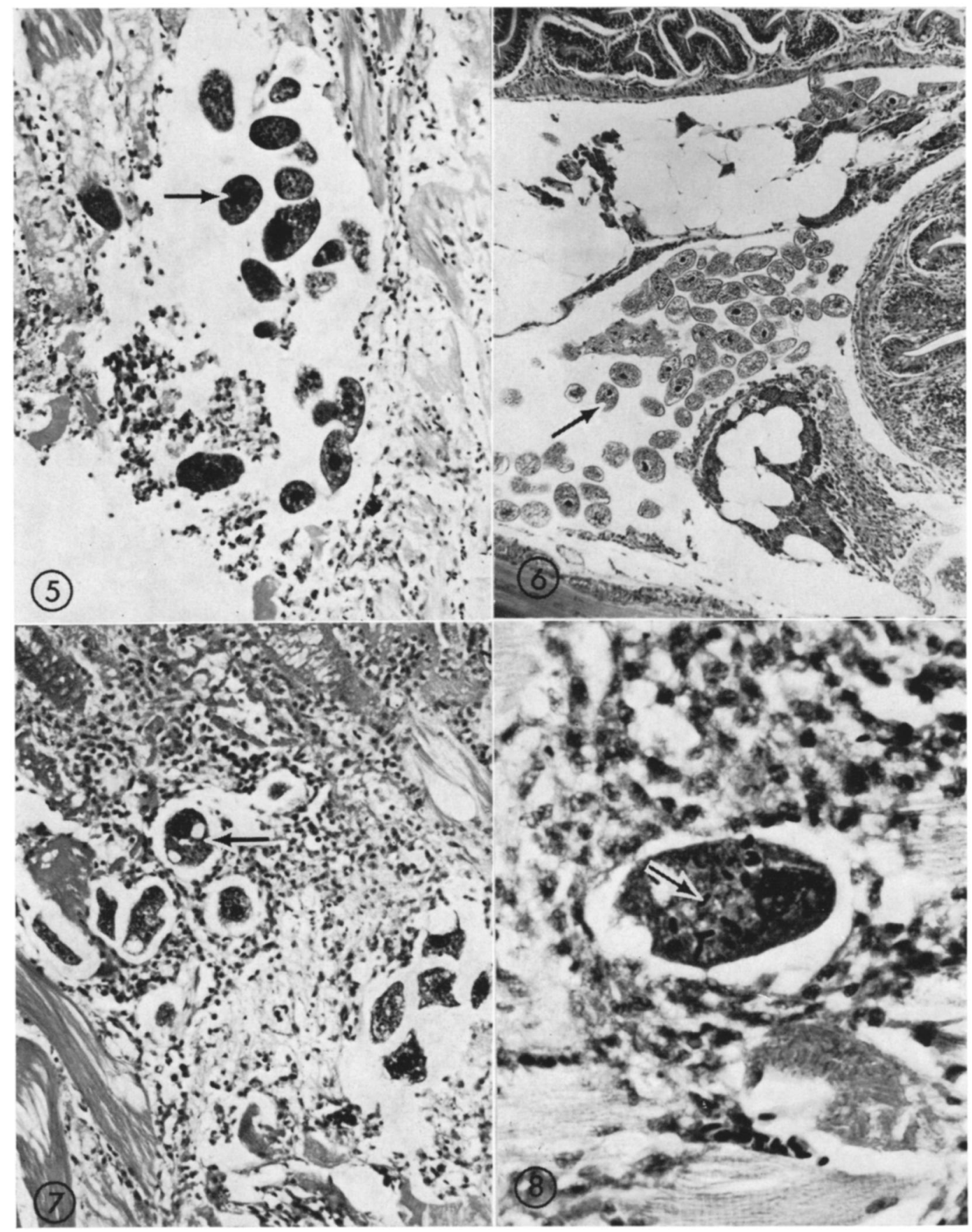

Figures 5-8. Tetrahymena corlissi and histopathology. 5. Lesion near surface of fish; epithelium has been eroded. Parasites (arrow) have penetrated body muscle. $\times 293$. 6. Parasites (arrow) have invaded coelom. Cecum and pancreatic tissue to the right. No tissue reaction. $\times 166$. 7. Tetrahymena corlissi (arrow) deep in muscle with marked cellular reaction. Muscle necrosis at top. $\times 302$. 8. Nuclei of ingested red cells (arrow) in vacuole of Tetrahymena corlissi. $\times 868$. 
Tetrahymena, using time lapse cinemicrography. In some cases there was a strong inflammatory response in areas of the dermis and musculature that Tetrahymena invaded (Fig. 7); since other cases lacked an inflammatory response, secondary bacterial infection may have caused the inflammation. Although some of the organisms that had penetrated deeply were surrounded by fibroblasts, no connective tissue capsule was formed by the host to wall off the parasites. Many of the ciliates had ingested erythrocytes, the nuclei of which were seen in vacuoles (Fig. 8).

On three occasions, we failed to infect healthy fish from a disease-free source with T. corlissi from diseased fish; F. Meyer (pers. comm.) reported the same results but noted that female progeny of infected females were infected. In contrast, Corliss (1960) reported experimental invasion of other animals by Tetrahymena, and Thompson (1958) infected artificially wounded guppies with $T$. corlissi.

\section{DISCUSSION}

Tetrahymena is typically a free-living ciliate. Under conditions which are yet to be identified, however, it apparently is invasive and may contribute to or even cause death. The failure of our attempts to transmit $T$. corlissi may reflect avirulence, lack of environmental factors essential to invasion, lack of host debilitation, or presence of host resistance. The presence of the organism in diseased fishes, and especially the histopathological findings, support a hypothesis of cause and effect. We do not, however, rule out the possibility that the ciliate follows a primary invader such as a bacterium. Bacteriological and virological examinations were not made.

The first report of Tetrahymena sp. from fish is that of Corliss (1953a) who found it in the peduncle musculature and spinal canal of a 15-mm rainbow trout in Paris.

Tetrahymena corlissi Thompson (1955) was originally described in abstract only as a facultative parasite in the circulatory system of a Pseudotriton larva. There is another record of invasion in catfish, Ameiurus sp., by Speidel (1958) where a ciliate identifiable most probably as $T$. corlissi was found in the developing central nervous system in young embryos.
Prior to the naming of T. corlissi by Thompson (1955) there are several reports that very likely concerned $T$. corlissi, according to Corliss (1960). The first report of an apparent Tetrahymena infection of vertebrates is that of Epstein (1926) who studied a fatal infection of bream (Abramis brama) with "Glaucoma sp."; the ciliate invaded the intestine, vascular system, and spinal canal of 7-mm fry. Shumway (1940) found ciliated protozoa (presumably Tetrahymena sp.) in the central nervous system of 12-mm laboratory-reared salamanders (Ambystoma texanum) at Urbana, Illinois. There are further reports of Tetrahymena spp. from amphibia from Massachusetts, New Hampshire, and Virginia (Corliss, 1954).

Knight and McDougle (1944) found a related species, T. pyriformis, in the infraorbital and other sinuses, digestive tract, etc., of 9-week-old chicks at Columbia, Missouri. A possible Tetrahymena sp. "Balantidium-like ciliate" has even been reported from the spinal fluid of a 6-year-old boy from Texas (Seamster, 1952).

Following the above reports there have appeared abstracts of three studies concerning Tetrahymena in fish: guppies (Missouri); guppies, platyfish, kissing gourami, African lungfish (New York Aquarium); and bullheads (Massachusetts) (Nance, 1954; Nigrelli, Jakowska, and Padnos, 1956; Speidel, 1958). In most instances there was extensive tissue invasion but the species were not identified or described. However, unpublished studies by Dr. Ruth McClung Jones (cited in Corliss, 1960) showed that Nance's guppy epizootics were caused by $T$. corlissi.

The mode of entry of Tetrahymena spp. is not known. It has been assumed that wounded or malnourished tadpoles and fish are more susceptible (Corliss, 1960), but other factors such as type of feed, organic load in the water, gaseous composition of water, temperature optima, and population densities of fish and ciliates have not been adequately studied. Tetrahymena may well serve as a classic example of the evolutionary development of endoparasitism (Corliss, 1972).

Until more is known, Tetrahymena should be treated with methods used for the somewhat similar ichthyophthiriasis. These methods, how- 
ever, do not kill parasites that have already invaded tissues.

\section{ACKNOWLEDGMENTS}

We thank J. Lom for supplying information on the California epizootic, assisting with the diagnostic key, and reviewing the manuscript; G. E. Cosgrove and A. M. Martin for sections of infected guppies; G. W. LeFever for live guppies; J. D. Hubbard for diagnostic assistance; S. L. Kazubski for help with the diagnostic key; and J. O. Corliss, G. E. Cosgrove, and R. J. Roberts for reviewing the manuscript.

\section{LITERATURE CITED}

Bykhovskaya-Pavlovskaya, I. E., M. N. Dubinina, A. V. Gusev, N. A. Izyumova, L. F. Nagabina, E. V. Rajkova, G. A. Shtein, S. S. Shulman, T. S. Smirnova, I. L. Sokolovskaya, and Yu. A. Strelkov. 1962. Key to parasites of freshwater fish of the USSR. Zool. Inst. Acad. Sci. USSR (English transl. TT 64-11040, NTIS, Dept. Commerce, Springfield, Va., 919 p).

Corliss, J. O. 1953a. Comparative studies on holotrichous ciliates in the Colpidium-Glaucoma-Leucophrys-Tetrahymena group. II. Morphology, life cycles, and systematic status of strains in pure culture. Parasitology 43 : 49-87.

- 1953b. Silver impregnation of ciliated protozoa by the Chatton-Lwoff technic. Stain Tech. 28: 97-100.

1954. The literature on Tetrahymena: its history, growth, and recent trends. J. Prot. 1 : $156-169$.

- 1960. Tetrahymena chironomi sp. nov., a ciliate from midge larvae, and the current status of facultative parasitism in the genus Tetrahymena. Parasitology 50: 111-153.

- 1970. The comparative systematics of species comprising the hymenostome ciliate genus Tetrahymena. J. Prot. 17: 198-209.

- 1972. Tetrahymena and some thoughts on the evolutionary origin of endoparasitism. Tr. Am. Micr. Soc. 91: 566-573.

Epstein, H. V. 1926. Infektion des Nervensystems von Fischen durch Infusorien. Arch. Russ. Protist. 5 : 169-180.

Ergens, R., And J. Lom. 1970. Puvodei Parasitarnich Nemoci Ryb (Principal Parasitic Diseases of Fishes). Academia Praha, Czech., 383 p. (in Czech).

Hoffman, G. L. 1967. An unusual case of fish disease caused by Ophryoglena sp. (Protozoa:
Hymenostomatida). Bull. Wildl. Dis. As. 3 : 111-112.

Knight, D. R., And H. C. McDougle. 1944. A protozoan of the genus Tetrahymena found in the domestic fowl. Am. J. Vet. Res. 5: 113116.

Krascheninnikow, S. 1953. The silver line system of Chilodonella cyprini (Moroff). J. Morph. 92 : 79-114.

Migala, K., and S. L. Kazubski. 1971. Nonspecific ciliates on cyprinid fishes in water ponds. J. Prot. 18 (Suppl.) : 31.

- AND 1972. Occurrence of nonspecific ciliates on carps (Cyprinus carpio L.) in winter ponds. Acta Protozoologica (Warsaw), 9(22): 329-337 (in English).

Mugard, Hélène. 1948. Development of the number of kineties of the cycle of growth and division in a ciliate: Ichthyophthirius multifiliis Fouquet. (In French.) Arch. d'Anat. Microscop. 37: 204-313. (In English: TT 59-52013.)

NANCE, S. F. 1954. A protozoan parasite of Lebistes reticulatus. (Abstr.). Bull. S. C. Acad. Sci. 16: 19.

Nigrelli, R. F., Sophia Jakowska, And M. PADNos. 1956. Tetrahymena as pathogenic epibiont in fishes and urodeles. J. Prot. 3 (Suppl. ) : 10.

Purnom, C. E., ANd A. E. Howard. 1971. Ciliate infestations: a problem in marine fish farming. J. du Conseil Int. pour I'Expl. de le Mer 33 : 511-514.

Roque, M., P. DePuytorac, AND J. Lom. 1967. The buccal architecture and the stomatogenesis of Ichthyophthirius multifiliis Fouquet, 1876. (In French.) Protistologica 3 : 79-90. (Partial English transl., Eastern Fish Disease Laboratory, Kearneysville, WV.)

Seamster, A. 1952. An unusual ciliate infection of the spinal fluid. Tex. J. Sci. 4: 531-532.

Shumway, W. 1940. A ciliate protozoon parasitic in the central nervous system of larval Ambystoma. Biol. Bull., Woods Hole 78: 283-288.

Speidel, C. C. 1954. Some histological changes in tissues of tadpoles under attack by ciliated protozoa. (Abstr.). Anat. Rec. 120: 756.

1958. The occurrence of amicronucleate tetrahymenae as facultative parasites in embryos of the catfish Ameiurus. (Abstr.). Biol. Bull., Woods Hole 115: 366.

Thompson, J. C., JR. 1955. Morphology of a new species of Tetrahymena. (Abstr.). J. Prot. 2 (Suppl.) : 12.

-1958. Experimental infections of various animals with strains of the genus Tetrahymena. J. Prot. 5 : 203-205. 